
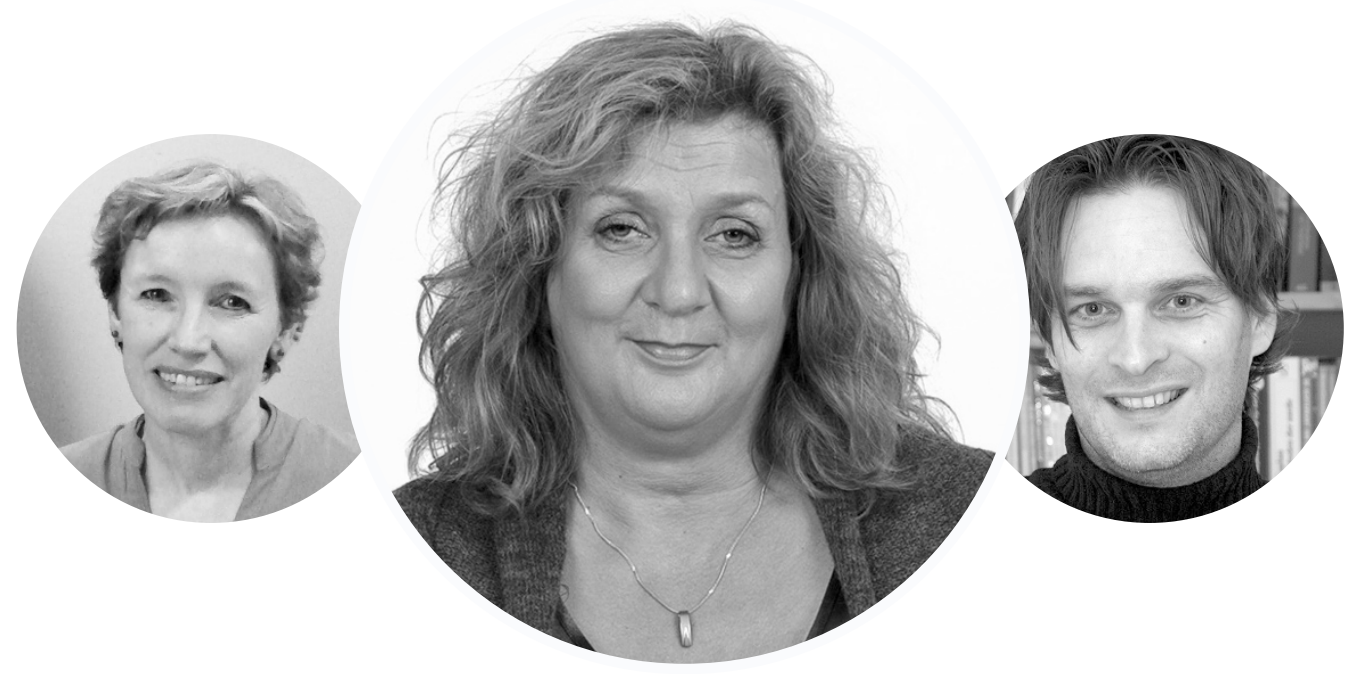

Tineke de Waard

\section{Nepnieuws en waarlijke feiten}

Wat worden sociaal werkers toch vaak geconfronteerd met nieuwe inzichten en feiten.We krijgen ze te horen van beleidmakers, lezen ze in de media en ze waaien vaak mee met nieuwe winden. Niet zelden hanteren betrokkenen deze nieuwe inzichten als mantra's, en passen zij nieuwe werkwijzen, als ware het haarlemmerolie, onmiddellijk toe. Misschien ben je sprankelend vers in het sociale domein en absorbeer je leergierig alles wat op je afkomt. Natuurlijk ben je vóór participatie en sta je open voor uitspraken als: 'Bezuinigingen in de ggz zorgen voor een toename van verwardheid bij kwetsbare mensen'. Jonge mensen die het vak kiezen om mensen te helpen wordt uitgelegd dat wij helpen door mensen en hun netwerk zelfredzaam te maken. En dat de Participatiewet het samenredzaam-zijn bevordert. Als je meer 'van de feiten' bent, loop je een paar keer om zo'n nieuw inzicht heen. Soms herken je het dan van eerdere tijden, soms is het verrassend nieuw. In veel initiële opleidingen is op dit moment Bildung, persoonsvorming van de aankomend professional, belangrijk. Met verschillende dimensies van professionaliteit kijken naar de complexiteit van het vak. Het 'kunnen' neemt dan ook een belangrijke plek in, zo niet de belangrijkste, veel meer dan Ausbildung: het beroepsmatig weten. We leren studenten op hun handen te zitten en de regie te laten bij de mensen met een vraag. Maar we willen natuurlijk niet dat die handen daardoor gaan slapen. Het zelf leren nadenken, een mening vormen, onderzoeken en ondernemen houdt het jonge brein wakker. En dat is maar goed ook. Laten zij zelf leren nadenken of en wanneer zij daadwerkelijk helpen, en wanneer ze vooral zelfredzaamheid bevorderen. In welke context mensen zich zien en erkend weten als klant, cliënt of patiënt: de lijdende mens. Laat ze op zoek gaan naar de feiten en de emotie gebruiken om hun empathisch vermogen te ontwikkelen en vergroten. Laat ze leren nepnieuws te checken door onderzoeken te raadplegen.

Zo blijkt uit onderzoek van Mark Peters, Maurice Gesthuizen en Peer Scheepers dat de verzorgingsstaat, met hogere uitgaven aan sociale zekerheid, de sociale participatie van burgers juist bevorderde. En daarmee dus ook de samenredzaamheid. Die terugtrekkende overheid heeft dus blijkbaar geen participatie tot gevolg die we als sociaal werkers door middel van het vergroten van zelfredzaamheid vooral dienen te stimuleren En uit onderzoek van de zorgverzekeraars in Nederland blijkt dat de bezuinigingen bij de ggz an sich helemaal niet hebben geleid tot meer overlast gevende verwarde personen en dat we goed moeten weten welke definities we hanteren.

Als we onze nieuwe collega's ogen, oren, hoofd en hart leren gebruiken dan komen die handen vanzelf op het juiste moment in actie. Of niet.We moeten ons blijven afvragen wat de waarlijke feiten zijn: de diepere waarheid die verborgen kan zitten onder het snelle nieuws en haastig getrokken conclusies. 